\title{
Effect of Shadow Banking Activities on the Financial Conditions of Vietnam Securities Company
}

\author{
Tran Thi Xuan Anh \\ Finance Department, Banking Academy, Hanoi, Vietnam; Email: ttxahvnh@gmail.com \\ Le Quoc Tuan \\ College of Management, Yuanze University, Taiwan; Email: tuanlq.hvnh@gmail.com
}

Doi:10.5901/mjss.2016.v7n5p27

\begin{abstract}
This paper study the impact of shadow banking activities on the financial conditions in different aspects, which are measured by CAEL rating system and its components, of Vietnamese securities firms. The shadow banking services are found to have negative effect on the overall financial soundness of the securities companies. In componential aspects, although positively related to Earnings, those services also negatively affect Securities firms' Capital adequacy, Asset quality and Liquidity. The effect is also stronger for those companies that do not meet the requirement of the regulations to provide official credit services and rely heavily on under-regulated shadow banking activities based on the inefficiency of current law and regulations.
\end{abstract}

Keywords: shadow banking, CAEL, financial conditions, securities firms, credit services

\section{Introduction}

In the recent years, shadow banking activities have been one of the topics of interest to the researchers. Many researchers have found the relationship between the shadow banking and the fragility and instability of the financial system. Others tried to develop models to measure the size and to monitors shadow banking activities at macroeconomic level. Nevertheless, few studies have been done on the effect of these activities on the financial conditions of the shadow bankers themselves. Some researches on this topic on financial institutions (banks or investment banks as an example) have illustrated the effect in some aspects of financial conditions such as capital, asset or profitability. As far as we know, none of these studies has considered the effect on the overall financial status of the shadow banking institutions.

In this paper, we study the impact of shadow banking activities of Vietnam securities companies on their financial conditions. We use the CAEL ratings system and its components to proxy for the overall and componential status of the securities firms. We found that despite having some positive impact on the profitability, shadow banking (in the form of implied credit services in Vietnam) deteriorates the financial soundness of securities companies, especially in capital adequacy, asset quality and liquidity aspects. The effect is stronger for those companies that rely on un-regulated shadow banking services that developed based on the loopholes of the Securities Law and regulations. The paper is constructed as follows: section II will provide review of literature on this field; section III briefly introduces the development of Vietnam securities firms and their shadow banking activities; section IV is for hypotheses development; section V describes the data and methodology; Section VI demonstrates the results and Section VII concludes.

\section{Literature Review}

The term shadow banking was proposed by Paul McCulley, the executive director of Pacific Investment Management Company, in his speech at Federal Reserve Bank of Kansas City's Economic Symposium in Jackson Hole, Wyoming, 2007. It is related to the banking activities that are conducted by institutions outside of traditional banks. Bernanke (2013) identified shadow banking as "comprise of a diverse set of institutions and markets that, collectively, carry out traditional banking functions but do so outside or in ways only loosely linked to, the traditional system of regulated depository institutions". He stated the examples for shadow banking institutions as: securitization vehicles, asset backed commercial paper (ABCP) conduits, money market mutual funds, markets for repo, investment banks and mortgage companies. The term "shadow" in "shadow banking" does not necessarily mean illegal, but rather the characteristics of the shadow 
banking activities. Gandhi (2014) pointed out those characteristics of shadow banking institutions:

Provide credit and liquidity services outside traditional banking.

- Not as tightly regulated as commercial banks

- Raise funds mostly through market-based instruments

- Have Government guarantee for liabilities to only a limited extent

- In time of distress, could not access to central bank liquidity.

In this manner, the credit activities, direct or indirect, from investment banks are considered shadow banking. They are credit for assets investment, which are often outside the scope of commercial banks. They are not well-regulated and receive almost no supervisory activities. Investment banks also often raise funds from market-based instruments and they could not access central bank as the lender of last resort when the distress occurs. The Financial Stability Board (2015) identified the investment banks shadow banking activities as: intermediation of market activities that is dependent on short term funding or on secured funding of client assets (In the Economic Function group: EF3).

The previously stated features of shadow banking are potentially harmful for the overall stability and financial conditions of the financial systems. There is a strand of literature studying the effect of shadow banking on the financial market and contagious problems to the whole system. Pozsar et al (2010); Adrian and Ashcraft (2012); Adrian, Ashcraft, Cetorelli (2013) and Adrian (2014) found that shadow banking could negatively impact financial system stability due to their regulatory arbitrage, neglected risks, funding fragilities as well as their high leverage and agency problem. They also developed quite a number of models to monitor shadow banking for regulatory bodies. Zou, Pang and Zhu (2012), with co-integration test and error correction model, demonstrated that overgrowth of shadow banking will increase financial fragility of the system. But how exactly is it for shadow banking to be considered overgrowth? Maeno et al (2014) developed a model to show that a run on shadow banking will lead to contagious collapse of commercial banks when the market share of shadow banking is at 10\% to 50\%. Luck and Schempp (2014), Ferrante (2015) and Liu, Shao and Gao (2016) indicated that large size of shadow banking is instable since it increases the aggregate leverage of financial sector, amplifying the exogenous shock. Banking safety net would not be able to prevent banking crisis if there was a run on shadow banking and the shutdown of securities market may have a long lasting consequences for real investment, output and consumption.

In a smaller scale, the shadow banking activities may cause risks to the shadow banking institution (shadow banker) itself. There are a few studies conducted on the effect of shadow banking activities on the financial conditions of the shadow bankers, which also directly related to this paper. To the extent that commercial banks take part in the shadow banking activities (which is possible if the commercial banks also use market-based instruments, securitization or other products, to mobilize funds and use funds for non-traditional banking activities), the commercial banks may also be considered shadow banks. Duca (2014) showed that in the long run, shadow banking share is negatively related to information costs and positively related to financial innovation and capital requirement burden on banks. In the short run, shadow banking has negative relationship with liquidity and positive to regulation that favor non-bank credit intermediation. Tang and Wang (2016) found a positive relationship between shadow banking activities and returns as well as risk-adjusted returns of China commercial banks who attended shadow banking. Meanwhile, Van $\mathrm{Ha}$ et al (2015) illustrated a negative effect of shadow banking activities on profitability and positive effect on non-performing loans (bad debt) of shadow bankers in Vietnam. Thanh Phuong et al (2012) found that shadow banking credit have positive relation with total non-performing loans and negative relation with capital adequacy of shadow bankers.

There is also another strand of study on shadow banking activities which is also crucial for this paper is on how to measure the size of shadow banking at several levels. Since the size of shadow banking affects not only the financial conditions of shadow bankers but the stability of the whole financial system as well, identifying the size of those activities at the firm and system level is meaningful. Measurement of shadow banking often came from the balance sheet approach, either from the asset side (credit from shadow banking products) or liability side (funds raised from marketbased instruments for shadow banking services). For instance, Poszar et al (2013) looked at all the liabilities recorded in the flows of funds that related to securitization activities and short-term money market transactions not backstopped by deposit insurance. Financial Safety Board (FSB), in their Global Shadow Banking Monitoring Report of 2012 to 2015, identified all financial assets of shadow bankers as shadow banking activities. Arquié and Artus (2013), considered all balance sheet items (from asset side) of shadow bankers that imply a form of credit toward the private sector of the economy.

\section{Vietnam Securities Firms Development and Shadow Banking Activities}

The year 2000 marked the birth of Vietnam Stock Market with one stock exchange, 2 listed companies and 6 securities 
companies. Since then, the stock market and securities firms of Vietnam have been growing continuously. The number of securities firms has increased significantly, peaked in the period of 2009-2011 with 105 companies. However, the stroke from global financial crisis and the following recession created tremendous difficulties for the securities firms. In 2008, from the peak of nearly 1,170.67 point, VN-index dropped remarkably to 235.50 point in 2009 (approximately 80\%). After that period, Vietnam stock market fluctuated around 400 and 600 point, trading activities have not been so high as the period before 2008 .

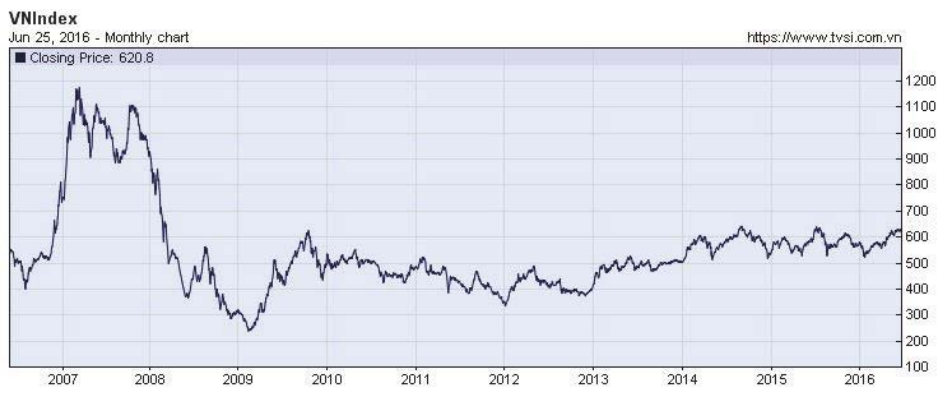

Figure 1. VN-index since 2007

Source: Tan Viet Securities Joint Stock Company

Vietnam securities companies have been facing fierce competition after the crisis. By the end of 2011, there are only 1.1 million trading accounts, and this number only grew to 1.27 million in 2013. With 85 companies still in operation at that time, it translated to about 14,900 accounts per companies. When compared to other countries at that time, the market size for each company is much smaller. For instance, China stock market ${ }^{1}$ has 106 securities companies but 53,7 million trading accounts (more than 506,000 accounts for each company); Thailand ${ }^{2}$ market has 37 securities companies and approximately 1.36 million accounts (36,800 accounts per company) or India ${ }^{3}$ with 13.1 million trading accounts and 279 securities firms (46,600 accounts for each firm). Also, the market share for Vietnam was not equal for all securities firms but concentrated to several large firms, small firms got very little market share. Therefore, many companies with weaker financial conditions have to struggle to survive with decreasing profitability, capability to provide services and debt payment.
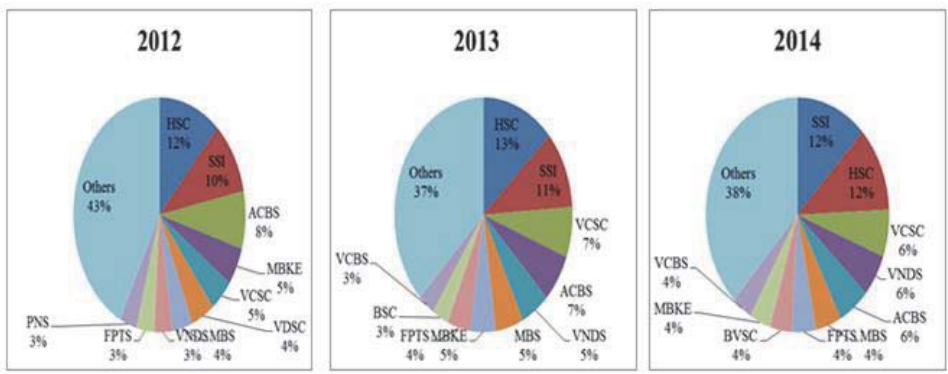

Figure 2. Market share of Securities Firms (2012-2014)

Source: Hochiminh Stock Exchange-www.hsx.vn

Small brokerage market that relies mostly on stock market trading has forced the securities firms to find other services to offer to customers in order to earn more revenue and maintain normal operation. Therefore, most of the securities

\footnotetext{
1 From China Securities Depository and Clearing annual report, available to download at: http://www.chinaclear.cn/english/annu/ about_alist.shtml

${ }^{2}$ From the Stock Exchange of Thailand, available at: $h$ ttp://www.set.or.th/tsd/en/download/statistic.html

${ }^{3}$ From the National Securities Depository Limited of India, available at: https://nsdl.co.in/about/facts-figs.php
} 
companies have tried to develop shadow banking services for individual and institutional investors, especially financial support, or credit services. Before 2008, some companies have already developed credit support in the form of margin trading. However, the State Securities Commission (SSC) has attributed excessive and aggressive margin credit from securities firms to the stock market bubble in 2008 and thus prohibited all direct credit services of securities companies from 2009 to 2011. In this period, despite the ban from SSC, Vietnam securities firms have found loopholes on the regulation to continue their shadow banking services. Examples of some of the shadow banking services provided by those firms are (according to Thanh Phuong et al (2012)):

- Investment Cooperation Contracts: The firm signed a contract with a high net-worth customer in a form of "investment cooperation" in which the customer provide 50 to $60 \%$ the value of the securities investment, the securities company provide the rest. The securities invested are kept by the company as collateral. The customer is required to pay a fixed amount of "profit share" (interest in nature) to the company as a fee. This form of contract effectively turned the loan relationship into joint investment relationship.

- Investment Settlement Guarantee: The firm signed a contract with customer to allow the customer to make a transaction even when the customer does not have enough money in his trading account up to 40 to $50 \%$ value of the transaction. The remaining value will be "guaranteed" by the company's assets.

- Advances for investors: According to the current settlement scheme $(T+3)$, when the customer liquidates his investment today (day 0), he could receive the proceeds after 3 trading days. However, with Advance services, the securities companies may provide the customers the funds up to $90 \%$ the value of proceeds from selling right at day 0 and received the proceeds after 3 trading days. The fee for this service is charged every day, even weekends and holidays. This is, in nature, a secured very short-term loan.

- Reverse Repurchase Agreements: The securities company signs an agreement with the customer to temporarily buy his/her securities to provide the customer an amount of fund. After a period, the company sells the securities back to the customer at a higher price (the difference is the interest payment of the customer).

Those "Pseudo" credit services are often under-regulated by the SSC since, on the appearance, they seem to be investment-based services. Official margin trading activities are often safer for the investment banks if they follow regulations and risk management schemes by margin requirement (initial and maintenance rate) and sometimes, supervisory to some extent by regulatory bodies. Pseudo credit services, on the other hand, are left unsupervised, risk management framework and financial safety requirements are mostly voluntary. Revenues from those activities are often identified on the balance sheet as Other Revenues. Excessive providing of those services is also risky to securities firms since they receive no official guarantees, nor could they access to Central bank liquidity had any risk occurs.

In 2011, The Ministry of Finance and SSC officially allowed some forms of credit services, including margin trading, under Circular 74/2011/TT-BTC and Decision number 637/2011/QD-UBCK. Nevertheless, only the securities firms that meet the requirements set by SSC can provide the official margin trading and receive some supervisory by SSC. Until now, many other securities firms can only rely heavily on the pseudo credit services to maintain their operation.

\section{Hypotheses Development}

In this paper, we study the effect of shadow banking activities on the financial conditions of Vietnam securities firms. Most of the previous literature focused on the relationship between shadow banking and the fragility or stability of financial system as a whole, such as Pozsar et al (2010); Adrian and Ashcraft (2012), Luck and Schempp (2014), Ferrante (2015), found the negative impact on the financial system when the size of shadow banking activities is large enough. There are only a few studies on the impact of shadow banking activities on the financial conditions of the shadow bankers themselves. However, most of the results are negative impact and only focus on one or two aspects of financial soundness, such as profitability, capital adequacy or asset quality in form of bad debt. Previous literature found the difference in this relationship in different aspects: negative with capital adequacy (Thanh Phuong et al (2012)); positive with profitability (Tang and Wang (2016)) and positive with non-performing loan (Van Ha et al (2015)). This paper considers the financial conditions of all the aspects as well as the components of each aspect. The total effect of shadow banking activities may depend on the different impact on different components. However, with the existence of those under-regulated shadow banking activities, the risks they cause to the securities firms could out-weight the benefit in profitability they bring.

H1: The shadow banking activities have negative impact on the overall financial conditions of the securities firms that conduct them.

As previously stated, since 2011, a part of securities firms are allowed to conduct official credit service in form of margin trading. These firms may still provide some pseudo credit services to the customers such as 
advances for investors or reverse repurchase agreements. However, since their credit services are under the supervision of regulatory bodies, securities firms would have to comply with requirements and restrictions on the services. Other companies that are not allowed to provide official credit services still rely heavily on the pseudo credit services as the previous period. It is reasonable to believe that the risks from the shadow banking activities would be larger for them.

- $\quad$ H2: The impact of shadow banking activities is stronger for securities firms that rely mostly on pseudo credit services.

\section{Data and Methodology}

\subsection{Data and Variables}

Since there is no official data source on Vietnam stock market, the data in this paper is hand collected. All the financial data is from audited annually financial reports of the securities firms which came from Ho Chi Minh Stock Exchange (HOSE) from 2012 to 2014. We consider all securities firms in Vietnam market that still operate and report normally. In 2012, there were 91 companies; this number decreased to 89 in 2013 and 85 in 2014. We choose the period because from 2012, the Circular 165/2012/TT-BTC of Ministry of Finance required the securities firms to report the audited financial safety ratio which is one of the important components in CAEL rating system. This kind of reports can also be found and available for download from HOSE website.

In this paper, the overall and component financial conditions of Vietnam securities firms are measured by the CAEL rating system. The CAEL rating system used in our study takes root from the CAMEL rating system, first introduced in the U.S. in 1979 as "The Uniform Financial Institution Rating System". CAMEL consists of 5 components of financial conditions: Capital, Asset, Management, Earnings and Liquidity (in 1996, S: Sensitivity to market risks was added to form CAMELS). This rating system considers the financial status of a financial institution (it is flexible and could be used for various types of institutions, commercial banks, investment banks, etc.) as a whole (the CAMEL score) and as component (component score) to provide the regulatory bodies a good view on the financial conditions of the financial institutions. It works like an early alarm for the deterioration of a financial institution's stability and soundness for official intervention of the government, avoiding a large scale run. CAMEL rating system is used in a number of studies such as Christopolos et al (2011) used CAMEL rating system to show that the government should have intervened in Lehman Brothers soon enough when the alarming signs were shown in CAMEL.

In 2013, CAMEL rating system was developed in Vietnam for securities firms under the Decision No. 617/QDUBCKNN by SSC. The component M: management quality is hard to quantified and include controversial as well as company's private information. Therefore, we only use the financial components from the CAMEL rating system to form CAEL rating system as we did in Thanh Phuong et al (2014).

For the size of shadow banking activities, we follow the study of Arquié and Artus (2013), considering all balance sheet items (from asset side) of securities firms that imply a form of credit, including margin trading and other pseudo credit services, other direct loans to partners, loans to individuals, etc. After sum up all the shadow banking activities of each securities firm, we take the natural logarithm of total credit activities (since the CAEL rating system score is bounded within 0 and 100).

\subsection{Methodology}

With a set of both cross-sectional and time series dimension of the same securities overtime, we deploy the pooled regression and panel regression. For the panel regression, we first run a random effect regression then a fixed effect regression and perform the Hausman test for fixed and random effect. The result (not reported here) indicates that at 5\% significance level, the use of random effect could not be rejected. So we specify the random effect model used in this paper as:

CAEL or Component ${ }_{i t}=\beta_{0}+\beta_{1} \operatorname{Ln}(\text { CREDIT })_{i t}+\sum_{j=2}^{k} \beta_{j}$ Control $_{i t}+a_{i}+\varepsilon_{i t}$

In which CAEL and the component C, A, E, L came from Thanh Phuong et al (2014); Ln(CREDIT) is the natural logarithm of all shadow banking activities of securities company. For controls, we use some firm characteristics such as the number of services provided by each company and company age. For CAEL overall score, we expect the coefficient of Ln(CREDIT) to be negative. For each component, the expectations are different. We also include one dummy variable: LISTED which equals to 1 if the company is listed on the exchange and 0 otherwise. Most of the securities companies are financially qualified to be listed on Vietnam stock market. However, the listed companies would have to comply with 
regulations and supervised by the Exchange. Therefore, there may be difference in impact between listed and not listed firms.

To test the second hypothesis of stronger effect for firms that relied mostly on pseudo credit activities, we divide the original sample into two sub samples of those companies who are in the list of official credit services and those who are not and run the regressions again.

\section{Results and Analysis}

\subsection{The effect of shadow banking activities on securities firm financial conditions}

In this part, we report the results from the regression of CAEL and its components on the size of shadow banking activities. Table 1 shows the descriptive statistics of the variables.

Table 1. Descriptive Statistics of full sample

\begin{tabular}{|l|c|c|c|c|c|c|}
\hline & No. of observation & Mean & Median & Standard Deviation & Skewness & Kurtosis \\
\hline CAEL & 260 & 70.1288 & 71 & 14.1059 & -0.5469 & 2.9300 \\
\hline $\boldsymbol{C}$ & 260 & 74.8922 & 80 & 17.9942 & -0.8067 & 3.7607 \\
\hline $\boldsymbol{A}$ & 260 & 63.0539 & 62 & 20.4100 & -0.1984 & 2.1132 \\
\hline $\boldsymbol{E}$ & 260 & 49.3077 & 60 & 32.3665 & -0.4774 & 1.7606 \\
\hline $\boldsymbol{L}$ & 260 & 87.4000 & 100 & 22.1963 & -1.9105 & 6.2663 \\
\hline Ln(CREDIT) & 215 & 25.0801 & 25.2986 & 2.5401 & -1.2697 & 5.9786 \\
\hline $\boldsymbol{N}$ service & 260 & 3.2231 & 4 & 0.8723 & -0.5524 & 1.8149 \\
\hline Age & 260 & 7.5692 & 7 & 2.4806 & 1.4097 & 4.6994 \\
\hline
\end{tabular}

Table 2. Pearson correlation coefficient matrix for Variables

\begin{tabular}{|c|c|c|c|c|}
\hline & CAEL & Ln(CREDIT) & No of services & Age \\
\hline CAEL & 1.0000 & & & \\
\hline Ln(CREDIT) & $\begin{array}{c}-0.0572 \\
(0.4039)\end{array}$ & 1.0000 & & \\
\hline No of services & $\begin{array}{c}0.1276 \\
(0.0398)\end{array}$ & $\begin{array}{c}0.5279 \\
(0.0000)\end{array}$ & 1.0000 & \\
\hline Age & $\begin{array}{c}0.2381 \\
(0.0001)\end{array}$ & $\begin{array}{c}0.3140 \\
(0.0000)\end{array}$ & $\begin{array}{c}0.2801 \\
(0.0000)\end{array}$ & 1.0000 \\
\hline
\end{tabular}

Over the sample period, there are 260 observations for the CAEL rating scores. On average, Vietnam securities companies are at rank B level with Mean and Median of CAEL are 71 and 70.1288, respectively. The component with higher average score is Liquidity which top at A level of 87.4 and skew more toward 100. Lowest average score belongs to Earnings with the mean of 49.3 ( $\mathrm{D}$ level) and median of 60 (C level). The Pearson's correlation coefficient matrix reported in table 2 show the correlation between variables. From that table, the relationship between CAEL and Ln(CREDIT) seems negative. Control variables show expected positive relationship with CAEL.

Table 3. The effect of shadow banking activities on financial conditions

\begin{tabular}{|l|c|c|c|c|c|}
\hline \multicolumn{7}{|c|}{ Panel A. Regression with only Ln(CREDIT) as explanatory variable } \\
\hline Specification & $(1)$ & $(2)$ & $(3)$ & $(4)$ & $(5)$ \\
\hline & CAEL & C & A & E & L \\
\hline \multirow{2}{*}{ Intercept } & $78.6842^{\star *}$ & $87.2037^{\star \star *}$ & $112.2207^{\star \star \star}$ & -21.7995 & $115.3921^{\star \star \star}$ \\
& $(0.000)$ & $(0.000)$ & $(0.000)$ & $(0.270)$ & $(0.000)$ \\
\hline Ln(CREDIT) & -0.3094 & -0.437 & $-4.19^{\star \star *}$ & $2.9806^{\star \star *}$ & $-1.1575^{\star}$ \\
& $(0.363)$ & $(0.298)$ & $(0.000)$ & $(0.000)$ & $(0.078)$ \\
\hline No. of observations & 215 & 215 & 215 & 215 & 215 \\
\hline$R^{2}$ & 0.0033 & 0.0041 & 0.060 & 0.0592 & 0.0159 \\
\hline Panel B. Regression with Ln(CREDIT) and other control variables \\
\hline
\end{tabular}




\begin{tabular}{|c|c|c|c|c|c|c|c|c|c|c|}
\hline & \multicolumn{2}{|c|}{ CAEL } & \multicolumn{2}{|c|}{$\mathrm{C}$} & \multicolumn{2}{|c|}{$A$} & \multicolumn{2}{|c|}{$E$} & \multicolumn{2}{|c|}{$\mathrm{L}$} \\
\hline Specification & (1) & (2) & (3) & (4) & (5) & (6) & (7) & (8) & (9) & (10) \\
\hline Intercept & $\begin{array}{c}82.176^{\star \star \star} \\
(0.000)\end{array}$ & $\begin{array}{c}84.981^{\star \star \star} \\
(0.000)\end{array}$ & \begin{tabular}{|c|}
$88.269^{\star \star \star}$ \\
$(0.000)$
\end{tabular} & $\begin{array}{c}90.022^{\star \star \star} \\
(0.000) \\
\end{array}$ & $\begin{array}{c}114.84^{\star \star \star} \\
(0.000)\end{array}$ & $\begin{array}{c}114.90^{\star \star \star} \\
(0.000)\end{array}$ & \begin{tabular}{|c|}
-9.986 \\
$(0.551)$ \\
\end{tabular} & $\begin{array}{l}-7.397 \\
(0.654)\end{array}$ & $\begin{array}{c}115.92^{\star \star \star} \\
(0.000)\end{array}$ & $\begin{array}{c}122.48^{\star \star \star} \\
(0.000)\end{array}$ \\
\hline Ln(CREDI & $\begin{array}{c}-1.226^{\star \star *} \\
(0.001) \\
\end{array}$ & $\begin{array}{c}-1.247^{\star \star \star} \\
(0.001)\end{array}$ & $\begin{array}{c}-1.198^{\star \star *} \\
(0.009) \\
\end{array}$ & $\begin{array}{c}-1.212^{\star * \star} \\
(0.007) \\
\end{array}$ & $\begin{array}{c}-2.365^{\star \star \star} \\
(0.000) \\
\end{array}$ & \begin{tabular}{|c|}
$-2.367^{\star \star \star \star}$ \\
$(0.000)$
\end{tabular} & $\begin{array}{c}0.133 \\
(0.868) \\
\end{array}$ & $\begin{array}{c}0.113 \\
(0.887)\end{array}$ & $\begin{array}{l}-1.212 \\
(0.110)\end{array}$ & $\begin{array}{l}-1.262^{*} \\
(0.095) \\
\end{array}$ \\
\hline No of $s$ & $\begin{array}{l}2.767^{\star \star} \\
(0.038)\end{array}$ & $\begin{array}{c}2.082 \\
(0.143) \\
\end{array}$ & $\begin{array}{c}0.058 \\
(0.969) \\
\end{array}$ & $\begin{array}{l}-0.369 \\
(0.812) \\
\end{array}$ & $\begin{array}{c}2.567 \\
(0.226) \\
\end{array}$ & $\begin{array}{c}2.553 \\
(0.243) \\
\end{array}$ & $\begin{array}{c}9.772^{\star \star \star} \\
(0.002) \\
\end{array}$ & $\begin{array}{l}9.141^{* \star *} \\
(0.005)\end{array}$ & $\begin{array}{c}0.553 \\
(0.794) \\
\end{array}$ & $\begin{array}{c}-1.048 \\
(0.648) \\
\end{array}$ \\
\hline Age & $\begin{array}{l}1.341^{\star \star \star} \\
(0.001)\end{array}$ & $\begin{array}{c}1.188^{\star \star \star} \\
(0.001) \\
\end{array}$ & $\begin{array}{c}2.306^{\star \star \star} \\
(0.000)\end{array}$ & $\begin{array}{c}2.209^{\star \star \star} \\
(0.000)\end{array}$ & $\begin{array}{l}-0.161 \\
(0.759) \\
\end{array}$ & $\begin{array}{c}-0.164 \\
(0.762) \\
\end{array}$ & $\begin{array}{c}3.539^{* \star *} \\
(0.000) \\
\end{array}$ & $\begin{array}{c}3.397^{\star \star \star} \\
(0.000)\end{array}$ & $\begin{array}{l}-0.124 \\
(0.842) \\
\end{array}$ & $\begin{array}{c}-0.485 \\
(0.446) \\
\end{array}$ \\
\hline LISTED & & $\begin{array}{l}4.203^{\star} \\
(0.057)\end{array}$ & & $\begin{array}{c}2.626 \\
(0.368) \\
\end{array}$ & & $\begin{array}{c}0.081 \\
(0.980)\end{array}$ & & $\begin{array}{c}3.879 \\
(0.363)\end{array}$ & & $\begin{array}{c}9.833^{\star \star \star} \\
(0.006)\end{array}$ \\
\hline No. $\mathrm{C}$ & 215 & 215 & 215 & 215 & 215 & 215 & 215 & 215 & 215 & 215 \\
\hline Adjusted $\mathrm{R}^{2}$ & 0.0846 & 0.0958 & 0.1028 & 0.1023 & 0.0543 & 0.0499 & 0.2043 & 0.2031 & 0.0022 & 0.027 \\
\hline \multicolumn{11}{|c|}{ Panel C. Random Effect Panel Regression with Ln(CREDIT) and other control variables } \\
\hline & \multicolumn{2}{|c|}{ CAEL } & \multicolumn{2}{|c|}{ C } & \multicolumn{2}{|c|}{ A } & \multicolumn{2}{|c|}{$\mathbf{E}$} & \multicolumn{2}{|c|}{$\mathrm{L}$} \\
\hline Speci & (1) & $(2)$ & $(3)$ & (4) & (5) & (6) & $(7)$ & (8) & (9) & $(10)$ \\
\hline Intercept & $\begin{array}{c}89.092^{* \star *} \\
(0.000) \\
\end{array}$ & $\begin{array}{c}87.677^{\star \star \star} \\
(0.000)\end{array}$ & $\begin{array}{c}102.08^{\star \star *} \\
(0.000) \\
\end{array}$ & $\begin{array}{c}98.437^{\star \star \star} \\
(0.000) \\
\end{array}$ & $\begin{array}{c}99.983^{* \star \star} \\
(0.000) \\
\end{array}$ & \begin{tabular}{|c|}
$98.455^{\star * \star}$ \\
$(0.000)$ \\
\end{tabular} & \begin{tabular}{|c|}
-3.376 \\
$(0.878)$ \\
\end{tabular} & $\begin{array}{l}-2.888 \\
(0.881) \\
\end{array}$ & $\begin{array}{c}120.18^{* * *} \\
(0.000)\end{array}$ & $\begin{array}{c}126.33^{\star \star \star} \\
(0.000)\end{array}$ \\
\hline Ln(CREDIT) & $\begin{array}{l}-0.719^{*} \\
(0.053)\end{array}$ & $\begin{array}{c}-1.535^{\star \star \star} \\
(0.000) \\
\end{array}$ & $\begin{array}{c}-1.033^{\star \star} \\
(0.044)\end{array}$ & $\begin{array}{c}-1.771^{\star \star \star} \\
(0.000) \\
\end{array}$ & \begin{tabular}{|c|}
$-1.472^{\star \star \star}$ \\
$(0.005)$ \\
\end{tabular} & \begin{tabular}{|c|}
$-1.557^{\star \star \star}$ \\
$(0.006)$ \\
\end{tabular} & $\begin{array}{c}2.251^{\star \star \star} \\
(0.008) \\
\end{array}$ & $\begin{array}{l}-0.275 \\
(0.737) \\
\end{array}$ & $\begin{array}{c}-1.344^{\star *} \\
(0.043)\end{array}$ & $\begin{array}{l}-1.55^{\star *} \\
(0.041) \\
\end{array}$ \\
\hline No of & & $\begin{array}{c}2.252 \\
(0.245)\end{array}$ & & $\begin{array}{c}0.647 \\
(0.755)\end{array}$ & & $\begin{array}{c}0.526 \\
(0.865)\end{array}$ & & $\begin{array}{l}9.717^{\star *} \\
(0.014)\end{array}$ & & $\begin{array}{c}-0.773 \\
(0.788) \\
\end{array}$ \\
\hline Age & & $\begin{array}{c}1.746^{\star \star \star} \\
(0.000)\end{array}$ & & $\begin{array}{c}2.502^{\star \star \star} \\
(0.000)\end{array}$ & & $\begin{array}{c}0.279 \\
(0.692)\end{array}$ & & $\begin{array}{c}3.872^{\star \star \star} \\
(0.000)\end{array}$ & & $\begin{array}{c}-0.133 \\
(0.873) \\
\end{array}$ \\
\hline LISTED & & $\begin{array}{c}3.481 \\
(0.278) \\
\end{array}$ & & $\begin{array}{c}2.568 \\
(0.549) \\
\end{array}$ & & $\begin{array}{l}-0.744 \\
(0.871) \\
\end{array}$ & & $\begin{array}{c}3.351 \\
(0.559) \\
\end{array}$ & & $\begin{array}{l}9.261^{*} \\
(0.051)\end{array}$ \\
\hline No. of ob & 215 & 215 & 215 & 215 & 215 & 215 & 215 & 215 & 215 & 215 \\
\hline Adjusted R2 & 0.0033 & 0.1097 & 0.0041 & 0.1171 & 0.0600 & 0.0602 & 0.0592 & 0.2169 & 0.0159 & 0.0436 \\
\hline
\end{tabular}

This table shows the results of univariate and multivariate regression of CAEL rating score and its components' scores on the size of shadow banking activities measured by the natural logarithm of the value of all shadow banking credit services: Ln(CREDIT). No. of services is the number of services provided by a securities firm; Age is the number of years the company in operation since its establishment; LISTED is a dummy equal to 1 if the securities company is listed on the stock exchange and 0 otherwise. In the parentheses are the p-values. ${ }^{* *}$, ${ }^{* *}$ and * indicate significance level of $1 \%, 5 \%$ and $10 \%$, respectively.

The regression results of CAEL rating and component scores are reported in the table 3. Panel A shows the regression of CAEL and its component with only Ln(CREDIT) as the explanatory variable. For specification (1), the coefficient of shadow banking activities is negative but not significant. It seems that the net effect of shadow banking activities of Vietnam securities companies on their financial conditions is not significantly different from 0 or, in other words, the negative effects and positive effects are at balance. Specification (2) also shows a not significant result for the shadow banking coefficient. Specification (3) and (4) are consistent with findings from previous researches that the shadow banking activities help increase the profitability of the securities firms but deteriorate the asset quality. Finally, specification (5) shows a significantly negative relationship between shadow banking activities and the liquidity of securities companies.

In Panel B of table 3, we add the control variables into the models. When control variables appear in the regression, the coefficients of $\operatorname{Ln}(C R E D I T)$ in specification (1) to (4) turn to significant. However, it does not necessary mean that the effect of Ln(CREDIT) in those cases are significant, but rather that the control variables (Age to be specific in the $\mathrm{C}$ component) have correlated with the main explanatory variable. In specification (1) and (2), control variables show positive and significant, indicating that the firm that could provide more services, "older" firms and securities firms that are listed on the stock market tend to have higher CAEL overall score (in better financial conditions). In component $A$ : asset quality, the coefficient of $\operatorname{Ln}(C R E D I T)$ are significantly negative while other control variable show no significant effect confirming the strong relationship of shadow banking activities to asset quality. For Earnings component, Ln(CREDIT) show positive coefficients in specification (7) and (8) but they are not statistically significant while control variables Age and number of service are positive and significant. Specification (9) does not confirm the effect of shadow banking on liquidity and the significance of the Ln(CREDIT) in specification (10) seems to come from the correlation with LISTED.

Panel $\mathrm{C}$ of table 3 shows the results of random effect panel regression. The coefficients of LN(CREDIT) are 
significant in most of the case. In specification (1), although the result is weak, it confirms that the shadow banking activities do reduce the overall financial conditions of the securities companies. Negative and significant results for LN(CREDIT) also found in Capital, Assets and Liquidity components. In Earnings component, the results confirm the findings in Panel B, shadow banking activities seem to have positive relation with the profitability of the securities firms when stand alone. However, when control variables are added, the effect of Age and number of service subsume the shadow banking activities.

\subsection{Control for sample selection bias}

The results may be affected by sample selection bias when larger firms tend to provide shadow banking services while small firms would not have enough financial capacity to provide these types of credit services. In order to resolve the potential selection bias, we deploy the Heckman two-stage approach. First, we use the probit model for the probability of a securities firm to take part in shadow banking activities on the size of the company, measured by total revenue.

$\operatorname{Pr}($ Shadow Banking $=1)=\Phi\left(\beta_{0}+\beta_{1} \operatorname{Ln}(\text { Total Revenue })_{i t}+\varepsilon_{i t}\right)$

From the model, we predict the probability to calculate the Inverse Mills Ratio to put into the regression. The significance of Inverse Mills Ratio $(\lambda)$ indicates and controls for the selection bias in the model.

Table 4. Control for sample selection bias

\begin{tabular}{|c|c|c|c|c|c|c|c|}
\hline \multirow[t]{3}{*}{ First Stage } & \multirow{3}{*}{\begin{tabular}{|c|} 
Probit model \\
Probability of Shadow banking
\end{tabular}} & \multirow[t]{3}{*}{ Second Stage } & \multicolumn{5}{|c|}{ Heckman } \\
\hline & & & (1) & (2) & (3) & (4) & (5) \\
\hline & & & CAEL & C & A & $E$ & $\mathrm{~L}$ \\
\hline Intercept & $\begin{array}{c}-7.311^{\star \star \star} \\
(0.000)\end{array}$ & Intercept & $\begin{array}{c}116.69^{\star \star \star} \\
(0.000)\end{array}$ & $\begin{array}{c}105.89^{* \star \star} \\
(0.000)\end{array}$ & $\begin{array}{c}155.17^{\star \star \star} \\
(0.000)\end{array}$ & $\begin{array}{c}101.11^{\star \star \star} \\
(0.000)\end{array}$ & $\begin{array}{c}103.41^{\star * \star} \\
(0.000)\end{array}$ \\
\hline Ln(total revenue) & $\begin{array}{l}0.347^{\star \star \star} \\
(0.000)\end{array}$ & Ln(CREDIT) & $\begin{array}{c}-1.533^{\star \star *} \\
(0.000) \\
\end{array}$ & $\begin{array}{c}-1.039^{\star *} \\
(0.012)\end{array}$ & $\begin{array}{c}-3.355^{\star \star \star} \\
(0.000)\end{array}$ & $\begin{array}{l}-0.976 \\
(0.155) \\
\end{array}$ & $\begin{array}{l}-0.771 \\
(0.331)\end{array}$ \\
\hline No. of obs. & 260 & $\lambda$ & \begin{tabular}{|c|}
$-27.72^{\star \star \star}$ \\
$(0.000)$ \\
\end{tabular} & $\begin{array}{c}-13.633^{\star \star} \\
(0.019) \\
\end{array}$ & $\begin{array}{l}-31.32^{\star \star \star} \\
(0.000)\end{array}$ & $\begin{array}{c}-89.63^{\star \star \star} \\
(0.000) \\
\end{array}$ & $\begin{array}{c}8.739 \\
(0.319) \\
\end{array}$ \\
\hline & & \begin{tabular}{|l} 
No. of obs. \\
\end{tabular} & 215 & 215 & 215 & 215 & 215 \\
\hline Pseudo R2 & 0.1319 & $\mathrm{R}^{2}$ & 0.091 & 0.0095 & 0.1071 & 0.2484 & 0.0099 \\
\hline
\end{tabular}

This table reports the results of Heckman two-stage approach to control for sample selection bias, including a probit model of the probability that a securities company provide shadow banking services. The product of first stage, the inverse mills ratio $(\lambda)$ is then put into the original regression to control for sample selection bias. P-values are reported in parentheses. ${ }^{* *} ; * \star$ and * indicate the significance level of $1 \%, 5 \%$ and $10 \%$, respectively.

The significance of inverse mills ratio in those regressions indicates that there is sample selection bias in the data. However, after controlling for the bias, the shadow banking activities effects are still significant in CAEL total ratings as well as component $C$ and A. However, specification (4) and (5) show that the effects of Ln(CREDIT) on earnings and liquidity are not so significant. This may further depict that the relationship between Ln(CREDIT) on these two components may largely be based on sample selection bias.

The previous results are consistent with the first hypothesis to some extent. The shadow banking activities do have negative impact on overall financial conditions of securities companies. The strongest effect is at assets quality. There are some effects on capital adequacy. The positive relationship between shadow banking and earnings seem to be caused by sample selection bias and the negative relationship with liquidity is only very weakly supported.

\subsection{The difference in effect between companies with official credit services and companies relied heavily on pseudo services}

In the previous part, we have developed a hypothesis that the impact of shadow banking activities should be stronger for securities firms that rely mostly on pseudo credit services. In this part, in order to test this hypothesis, we divide the original sample into two groups: one with the securities firms which met the requirement of SSC and in the list to provide margin lending (or so-called the LEGAL group) and the other with securities firms that did not meet the requirement and rely only on the "pseudo" credit activities to compete (the PSEUDO group). Table 5 illustrates the summary statistics of these two groups. 
Table 5. Descriptive Statistics of sub samples

\begin{tabular}{|c|c|c|c|c|c|c|}
\hline & No. of observation & Mean & Median & Standard Deviation & Skewness & Kurtosis \\
\hline \multicolumn{7}{|c|}{ LEGAL GROUP } \\
\hline CAEL & 135 & 73.97 & 74 & 12.2849 & -0.6933 & 3.5379 \\
\hline C & 135 & 79.89 & 80 & 15.1709 & -0.6356 & 3.0211 \\
\hline$A$ & 135 & 64.49 & 68 & 18.2674 & -0.1482 & 1.9549 \\
\hline$E$ & 135 & 59.81 & 60 & 27.6532 & -0.9803 & 2.9310 \\
\hline$L$ & 135 & 86.99 & 100 & 21.8856 & -1.9035 & 6.3654 \\
\hline Ln(CREDIT) & 133 & 25.89 & 26.01 & 2.0430 & -1.2822 & 6.5704 \\
\hline N_service & 135 & 3.62 & 4 & 0.6449 & -1.4677 & 3.8727 \\
\hline \multirow[t]{2}{*}{ Age } & 135 & 8.04 & 7 & 2.8855 & 1.0815 & 3.2384 \\
\hline & No. of observation & Mean & Median & Standard Deviation & Skewness & Kurtosis \\
\hline \multicolumn{7}{|c|}{ PSEUDO GROUP } \\
\hline CAEL & 95 & 65.93 & 67 & 15.0199 & -0.3329 & 2.5497 \\
\hline$C$ & 95 & 69.61 & 70 & 19.7749 & -0.9207 & 3.8850 \\
\hline$A$ & 95 & 60.19 & 56 & 22.4771 & -0.0322 & 1.9437 \\
\hline$E$ & 95 & 41.45 & 50 & 33.7476 & -0.1177 & 1.4489 \\
\hline$L$ & 95 & 85.98 & 100 & 24.5489 & -1.7499 & 5.3303 \\
\hline $\operatorname{Ln}(\mathrm{CREDIT})$ & 83 & 23.84 & 24.42 & 7.2060 & -1.2712 & 5.9707 \\
\hline N_service & 96 & 2.81 & 3 & 0.8069 & 0.3589 & 1.6385 \\
\hline Age & 96 & 7.12 & 7 & 2.0012 & 1.4824 & 6.1823 \\
\hline
\end{tabular}

From the summary statistics, on average, the LEGAL group has higher CAEL total score and components score than their PSEUDO counterparts. The number of service provided by companies from LEGAL group is also higher than that of PSEUDO group. Finally, the age of the securities firms of LEGAL group is slightly higher than PSEUDO.

We then run the regression again for the two sub-samples to compare the effect. The regression results are reported in Table 6 and Table 7. These tables depict interesting results on the two groups. The effect of shadow banking activities on the financial conditions of securities companies in the LEGAL group is significantly negative in overall CAEL, Capital, Asset and Liquidity component. In some specification, there is positive relation between Ln(CREDIT) of LEGAL group and profitability. Control variables are positively related with financial conditions. The shadow banking activities of PSEUDO group, on the other hand, displays significantly negative relation with CAEL, C, A and no significant relation with $\mathrm{E}$ and $\mathrm{L}$. The control variables in PSEUDO group behave different. In Panel B of table 7, the number of services shows negative relationship with financial components and CAEL in specification (3), (4), (9), (10) indicating that, for companies in the PSEUDO groups, the more they expand and more services they try to develop, the worse their financial conditions become.

In term of magnitude, the coefficients of Ln(CREDIT) in table 7 for PSEUDO group are mostly larger in all 3 panels than that of LEGAL group for Capital and Asset Quality. This is consistent with the second hypothesis that the companies that rely heavily on pseudo shadow banking activities will have worse financial conditions than companies that are allowed to offer official credit services.

Table 6. The effect of shadow banking activities on financial conditions

- LEGAL GROUP

\begin{tabular}{|c|c|c|c|c|c|c|c|c|c|c|}
\hline \multicolumn{11}{|c|}{ Panel A. Regression with only Ln(CREDIT) as explanatory variable } \\
\hline Specification & \multicolumn{2}{|c|}{ (1) } & \multicolumn{2}{|c|}{ (2) } & \multicolumn{2}{|c|}{ (3) } & \multicolumn{2}{|c|}{$(4)$} & \multicolumn{2}{|c|}{$(5)$} \\
\hline & \multicolumn{2}{|c|}{ CAEL } & \multicolumn{2}{|c|}{ C } & \multicolumn{2}{|c|}{$A$} & \multicolumn{2}{|c|}{ E } & \multicolumn{2}{|c|}{ L } \\
\hline Intercept & \multicolumn{2}{|c|}{$\begin{array}{c}94.2096^{\star \star \star} \\
(0.000)\end{array}$} & \multicolumn{2}{|c|}{$\begin{array}{c}100.2016^{\star \star \star} \\
(0.000)\end{array}$} & \multicolumn{2}{|c|}{$\begin{array}{c}107.7575^{\star \star \star} \\
(0.000)\end{array}$} & \multicolumn{2}{|c|}{$\begin{array}{c}-19.3775 \\
(0.529)\end{array}$} & \multicolumn{2}{|c|}{$\begin{array}{c}162.4111^{* * *} \\
(0.000)\end{array}$} \\
\hline Ln(CREDIT) & \multicolumn{2}{|c|}{$\begin{array}{c}-0.7869^{\star} \\
(0.084)\end{array}$} & \multicolumn{2}{|c|}{$\begin{array}{l}-0.7901 \\
(0.161)\end{array}$} & \multicolumn{2}{|c|}{$\begin{array}{l}-1.671^{\star *} \\
(0.013)\end{array}$} & \multicolumn{2}{|c|}{$\begin{array}{c}3.0505^{\star * \star} \\
(0.010)\end{array}$} & \multicolumn{2}{|c|}{$\begin{array}{c}-2.919 * \star \star \\
(0.000)\end{array}$} \\
\hline No. of observations & \multicolumn{2}{|c|}{133} & \multicolumn{2}{|c|}{133} & \multicolumn{2}{|c|}{133} & \multicolumn{2}{|c|}{133} & \multicolumn{2}{|c|}{133} \\
\hline $\mathrm{R}^{2}$ & \multicolumn{2}{|c|}{0.0170} & \multicolumn{2}{|c|}{0.0113} & \multicolumn{2}{|c|}{0.0345} & \multicolumn{2}{|c|}{0.0504} & \multicolumn{2}{|c|}{0.0736} \\
\hline \multicolumn{11}{|c|}{ Panel B. Regression with Ln(CREDIT) and other control variables } \\
\hline & \multicolumn{2}{|c|}{ CAEL } & \multicolumn{2}{|c|}{ C } & \multicolumn{2}{|c|}{ A } & \multicolumn{2}{|c|}{$\mathrm{E}$} & \multicolumn{2}{|c|}{$\mathbf{L}$} \\
\hline Specification & (1) & $(2)$ & (3) & (4) & (5) & (6) & (7) & (8) & (9) & (10) \\
\hline Intercept & $97.682^{\star \star \star}$ & $97.207^{\star \star *}$ & $110.67^{\star \star *}$ & $110.10^{\star \star \star}$ & $107.64^{\star \star \star}$ & $107.54^{\star \star \star}$ & -11.92 & -11.82 & $158.12^{\star \star \star}$ & $156.96^{\star \star *}$ \\
\hline
\end{tabular}




\begin{tabular}{|c|c|c|c|c|c|c|c|c|c|c|}
\hline & $(0.000)$ & $(0.000)$ & $(0.000)$ & $(0.000)$ & $(0.000)$ & $(0.000)$ & $(0.596)$ & $(0.601)$ & $(0.000)$ & $(0.000)$ \\
\hline Ln(CREDIT) & $\begin{array}{c}-1.834^{* * *} \\
(0.000)\end{array}$ & $\begin{array}{c}-1.752^{* * \star} \\
(0.000)\end{array}$ & $\begin{array}{c}-1.804^{* * *} \\
(0.000)\end{array}$ & $\begin{array}{c}-1.707^{\star \star *} \\
(0.002)\end{array}$ & $\begin{array}{c}-1.629 * * \\
(0.021)\end{array}$ & $\begin{array}{c}-1.613^{\star *} \\
(0.023)\end{array}$ & $\begin{array}{l}-0.092 \\
(0.921)\end{array}$ & $\begin{array}{l}-0.108 \\
(0.909)\end{array}$ & $\begin{array}{c}-3.421^{* * \star} \\
(0.001)\end{array}$ & $\begin{array}{c}-3.222^{* \star \star} \\
(0.003)\end{array}$ \\
\hline No of service & $\begin{array}{c}4.092^{\star \star \star} \\
(0.007)\end{array}$ & $\begin{array}{l}3.581^{\star \star} \\
(0.017)\end{array}$ & $\begin{array}{l}-0.424 \\
(0.778)\end{array}$ & $\begin{array}{l}-1.031 \\
(0.493)\end{array}$ & $\begin{array}{l}-0.174 \\
(0.955)\end{array}$ & $\begin{array}{l}-0.277 \\
(0.929)\end{array}$ & $\begin{array}{c}14.101^{\star \star \star} \\
(0.000)\end{array}$ & $\begin{array}{c}14.204^{\star \star \star} \\
(0.001)\end{array}$ & $\begin{array}{c}5.638 \\
(0.131)\end{array}$ & $\begin{array}{c}4.398 \\
(0.246)\end{array}$ \\
\hline Age & $\begin{array}{c}1.096 \star \star \star \\
(0.002)\end{array}$ & $\begin{array}{c}0.974^{\star \star \star} \\
(0.008)\end{array}$ & $\begin{array}{c}2.152^{\star \star \star} \\
(0.000)\end{array}$ & $\begin{array}{l}2.008^{\star \star \star} \\
(0.000)\end{array}$ & $\begin{array}{l}-0.040 \\
(0.946)\end{array}$ & $\begin{array}{l}-0.065 \\
(0.917)\end{array}$ & $\begin{array}{c}2.833^{\star \star \star} \\
(0.000)\end{array}$ & $\begin{array}{c}2.858^{\star \star \star} \\
(0.000)\end{array}$ & $\begin{array}{l}-0.390 \\
(0.561)\end{array}$ & $\begin{array}{l}-0.658 \\
(0.342)\end{array}$ \\
\hline LISTED & & $\begin{array}{c}3.222 \\
(0.170)\end{array}$ & & $\begin{array}{c}3.825 \\
(0.166)\end{array}$ & & $\begin{array}{c}0.644 \\
(0.844)\end{array}$ & & $\begin{array}{l}-0.649 \\
(0.890)\end{array}$ & & $\begin{array}{l}7.815^{\star} \\
(0.054)\end{array}$ \\
\hline No. of observ & 133 & 133 & 133 & 133 & 133 & 133 & 133 & 133 & 133 & 133 \\
\hline Adjusted $\mathrm{R}^{2}$ & 0.1199 & 0.1278 & 0.1378 & 0.1447 & 0.0121 & 0.0047 & 0.2458 & 0.2400 & 0.0743 & 0.0943 \\
\hline \multicolumn{11}{|c|}{ Panel C. Random Effect Panel Regression with Ln(CREDIT) and other control variables } \\
\hline & \multicolumn{2}{|c|}{ CAEL } & \multicolumn{2}{|c|}{ C } & \multicolumn{2}{|c|}{ A } & \multicolumn{2}{|c|}{$\mathrm{E}$} & \multicolumn{2}{|c|}{$\mathbf{L}$} \\
\hline Specification & (1) & (2) & (3) & (4) & (5) & (6) & (7) & (8) & (9) & $(10)$ \\
\hline Intercept & $\begin{array}{c}92.867^{\star \star \star} \\
(0.000)\end{array}$ & $\begin{array}{c}88.777^{\star \star \star} \\
(0.000)\end{array}$ & $\begin{array}{c}106.91^{\star \star \star} \\
(0.000)\end{array}$ & $\begin{array}{c}110.43^{\star \star \star} \\
(0.000)\end{array}$ & $\begin{array}{c}90.398^{\star \star \star} \\
(0.000)\end{array}$ & $\begin{array}{c}95.449^{\star \star \star} \\
(0.000)\end{array}$ & $\begin{array}{l}-6.8803 \\
(0.797) \\
\end{array}$ & $\begin{array}{l}-18.83 \\
(0.303)\end{array}$ & $\begin{array}{c}156.85^{\star \star \star} \\
(0.000)\end{array}$ & $\begin{array}{c}148.13^{\star \star \star} \\
(0.000)\end{array}$ \\
\hline Ln(CREDIT) & $\begin{array}{c}-0.731^{\star *} \\
(0 . .048)\end{array}$ & $\begin{array}{c}-1.401^{\star \star \star} \\
(0.001)\end{array}$ & $\begin{array}{c}-1.045^{\star *} \\
(0.045)\end{array}$ & $\begin{array}{c}-1.747^{\star \star \star} \\
(0.001)\end{array}$ & $\begin{array}{l}-0.992 \\
(0.144)\end{array}$ & $\begin{array}{l}-1.165^{\star} \\
(0.087)\end{array}$ & $\begin{array}{c}2.573^{\star * \star} \\
(0.009)\end{array}$ & $\begin{array}{c}0.189 \\
(0.792)\end{array}$ & $\begin{array}{c}-2.705^{\star \star \star} \\
(0.000)\end{array}$ & $\begin{array}{c}-2.824^{\star *} \\
(0.011)\end{array}$ \\
\hline No of service & & $\begin{array}{c}2.783 \\
(0.168) \\
\end{array}$ & & $\begin{array}{l}-0.982 \\
(0.653) \\
\end{array}$ & & $\begin{array}{l}-2.461 \\
(0.600) \\
\end{array}$ & & $\begin{array}{c}13.308^{\star \star \star} \\
(0.002)\end{array}$ & & $\begin{array}{c}4.228 \\
(0.246) \\
\end{array}$ \\
\hline Age & & \begin{tabular}{|c|}
$1.262^{\star \star *}$ \\
$(0.006)$ \\
\end{tabular} & & $\begin{array}{c}2.079^{\star \star \star \star} \\
(0.000) \\
\end{array}$ & & $\begin{array}{c}1.032 \\
(0.212) \\
\end{array}$ & & \begin{tabular}{|c|}
$3.188^{* * *}$ \\
$(0.000)$ \\
\end{tabular} & & $\begin{array}{c}-0.802 \\
(0.409) \\
\end{array}$ \\
\hline LISTED & & $\begin{array}{c}3.177 \\
(0.349)\end{array}$ & & $\begin{array}{c}3.891 \\
(0.331)\end{array}$ & & $\begin{array}{c}0.088 \\
(0.986)\end{array}$ & & $\begin{array}{l}-0.605 \\
(0.924)\end{array}$ & & $\begin{array}{c}7.839 \\
(0.145)\end{array}$ \\
\hline No. of observations & 133 & 133 & 133 & 133 & 133 & 133 & 133 & 133 & 133 & 133 \\
\hline Adjusted $\mathrm{R}^{2}$ & 0.0170 & 0.1461 & 0.0113 & 0.1706 & 0.0345 & 0.0106 & 0.0504 & 0.2618 & 0.0736 & 0.1212 \\
\hline
\end{tabular}

This table shows the results of univariate and multivariate regression for LEGAL GROUP of CAEL rating score and its components' scores on the size of shadow banking activities measured by the natural logarithm of the value of all shadow banking credit services: Ln(CREDIT). No. of services is the number of services provided by a securities firm; Age is the number of years the company in operation since its establishment; LISTED is a dummy equal to 1 if the securities company is listed on the stock exchange and 0 otherwise. In the parentheses are the p-values. ${ }^{* *}$, ${ }^{*}$ and ${ }^{*}$ indicate significance level of $1 \%, 5 \%$ and $10 \%$, respectively.

Table 7. The effect of shadow banking activities on financial conditions

- PSEUDO GROUP

\begin{tabular}{|c|c|c|c|c|c|c|c|c|c|c|}
\hline \multicolumn{11}{|c|}{ Panel A. Regression with only Ln(CREDIT) as explanatory variable } \\
\hline Specification & \multicolumn{2}{|c|}{$(1)$} & \multicolumn{2}{|c|}{$(2)$} & \multicolumn{2}{|c|}{ (3) } & \multicolumn{2}{|c|}{ (4) } & \multicolumn{2}{|c|}{ (5) } \\
\hline & \multicolumn{2}{|c|}{ CAEL } & \multicolumn{2}{|c|}{$\mathrm{C}$} & \multicolumn{2}{|c|}{ A } & \multicolumn{2}{|c|}{$\mathrm{E}$} & \multicolumn{2}{|c|}{$\mathrm{L}$} \\
\hline Intercept & \multicolumn{2}{|c|}{$\begin{array}{c}98.938^{* \star \star} \\
(0.000)\end{array}$} & \multicolumn{2}{|c|}{$\begin{array}{c}116.937^{\star \star \star} \\
(0.000)\end{array}$} & \multicolumn{2}{|c|}{$\begin{array}{c}151.499 * * * \\
(0.000)\end{array}$} & \multicolumn{2}{|c|}{$\begin{array}{l}20.903 \\
(0.400)\end{array}$} & \multicolumn{2}{|c|}{$\begin{array}{c}90.161^{* * *} \\
(0.001)\end{array}$} \\
\hline Ln(CREDIT) & \multicolumn{2}{|c|}{$\begin{array}{c}-1.3778^{\star \star \star} \\
(0.000)\end{array}$} & \multicolumn{2}{|c|}{$\begin{array}{c}-1.9519^{\star *} \\
(0.011)\end{array}$} & \multicolumn{2}{|c|}{$\begin{array}{c}-3.8559^{\star \star \star} \\
(0.000)\end{array}$} & \multicolumn{2}{|c|}{$\begin{array}{l}0.8937 \\
(0.387)\end{array}$} & \multicolumn{2}{|c|}{$\begin{array}{l}-0.189 \\
(0.858)\end{array}$} \\
\hline No. of observations & \multirow{2}{*}{\multicolumn{2}{|c|}{82}} & \multirow{2}{*}{\multicolumn{2}{|c|}{82}} & \multirow{2}{*}{\multicolumn{2}{|c|}{$\begin{array}{c}82 \\
0.2020\end{array}$}} & \multicolumn{2}{|c|}{82} & \\
\hline $\mathrm{R}^{2}$ & 0.0651 & & & & & & \multicolumn{2}{|c|}{0.0053} & \multicolumn{2}{|c|}{0.0004} \\
\hline \multicolumn{11}{|c|}{ Panel B. Regression with Ln(CREDIT) and other control variables } \\
\hline & \multicolumn{2}{|c|}{ CAEL } & \multicolumn{2}{|c|}{$\mathrm{C}$} & \multicolumn{2}{|c|}{$\mathbf{A}$} & \multicolumn{2}{|c|}{$E$} & & $\mathbf{L}$ \\
\hline Specification & (1) & (2) & (3) & (4) & (5) & (6) & (7) & (8) & (9) & (10) \\
\hline Intercept & $\begin{array}{c}90.573^{\star \star \star} \\
(0.000)\end{array}$ & $\begin{array}{c}95.706^{\star \star} \\
(0.000)\end{array}$ & $\begin{array}{c}104.28^{\star \star \star} \\
(0.000)\end{array}$ & $\begin{array}{c}94.453^{\star \star \star} \\
(0.000)\end{array}$ & $\begin{array}{c}154.97^{\star \star} \\
(0.000)\end{array}$ & $\begin{array}{c}153.23^{\star \star \star} \\
(0.000)\end{array}$ & $\begin{array}{c}3.091 \\
(0.900)\end{array}$ & $\begin{array}{l}28.196 \\
(0.330)\end{array}$ & $\left\{\begin{array}{c}84.051^{\star \star} \\
(0.003)\end{array}\right.$ & $\begin{array}{c}96.225^{\star \star \star} \\
(0.001)\end{array}$ \\
\hline Ln(CREDIT) & $\begin{array}{l}-1.288^{\star \star} \\
(0.010)\end{array}$ & $\begin{array}{c}-1.402^{\star \star \star} \\
(0.005)\end{array}$ & $\begin{array}{c}-1.612^{* *} \\
(0.019)\end{array}$ & $\begin{array}{l}-1.394^{\star \star} \\
(0.035)\end{array}$ & $\begin{array}{c}-3.829^{\star \star \star} \\
(0.000)\end{array}$ & $\begin{array}{c}-3.791^{\star \star \star} \\
(0.000)\end{array}$ & $\begin{array}{l}-0.078 \\
(0.947)\end{array}$ & $\begin{array}{l}-0.634 \\
(0.594)\end{array}$ & $\begin{array}{c}0.588 \\
(0.572)\end{array}$ & $\begin{array}{c}0.318 \\
(0.765)\end{array}$ \\
\hline No of service & $\begin{array}{l}-2.822 \\
(0.242)\end{array}$ & $\begin{array}{l}-3.353 \\
(0.219)\end{array}$ & $\begin{array}{l}-5.679^{\star *} \\
(0.037)\end{array}$ & $\begin{array}{l}-4.661^{*} \\
(0.094)\end{array}$ & $\begin{array}{c}0.731 \\
(0.835)\end{array}$ & $\begin{array}{c}0.911 \\
(0.808)\end{array}$ & $\begin{array}{c}2.013 \\
(0.677)\end{array}$ & $\begin{array}{l}-0.585 \\
(0.909)\end{array}$ & $\begin{array}{l}-6.973^{\star \star} \\
(0.043)\end{array}$ & $\begin{array}{l}-8.234^{\star *} \\
(0.034)\end{array}$ \\
\hline Age & $\begin{array}{c}1.945^{\star * *} \\
(0.009)\end{array}$ & $\begin{array}{l}1.732^{\star \star} \\
(0.023)\end{array}$ & $\begin{array}{c}2.810^{\star \star \star} \\
(0.009)\end{array}$ & $\begin{array}{l}3.217^{\star \star \star} \\
(0.008)\end{array}$ & $\begin{array}{l}-0.848 \\
(0.366)\end{array}$ & \begin{tabular}{|c|}
-0.776 \\
$(0.461)$ \\
\end{tabular} & $\begin{array}{l}4.894^{\star \star \star} \\
(0.004)\end{array}$ & $\begin{array}{c}3.853^{\star \star} \\
(0.04)\end{array}$ & $\begin{array}{c}0.961 \\
(0.551)\end{array}$ & $\begin{array}{c}0.456 \\
(0.764)\end{array}$ \\
\hline LISTED & & $\begin{array}{c}4.284 \\
(0.411)\end{array}$ & & \begin{tabular}{|c|}
-8.206 \\
$(0.319)$ \\
\end{tabular} & & $\begin{array}{l}-1.453 \\
(0.866) \\
\end{array}$ & & $\begin{array}{l}20.95^{\star *} \\
(0.033) \\
\end{array}$ & & $\begin{array}{l}10.162 \\
(0.220)\end{array}$ \\
\hline
\end{tabular}




\begin{tabular}{|c|c|c|c|c|c|c|c|c|c|c|}
\hline No. of observations & 82 & 82 & 82 & 82 & 82 & 82 & 82 & 82 & 82 & 82 \\
\hline Adjusted R2 & 0.1126 & 0.1081 & 0.1642 & 0.1684 & 0.1769 & 0.2077 & 0.0629 & 0.0832 & 0.0076 & 0.0077 \\
\hline \multicolumn{11}{|c|}{ Panel C. Random Effect Panel Regression with Ln(CREDIT) and other control variables } \\
\hline & \multicolumn{2}{|c|}{ CAEL } & \multicolumn{2}{|c|}{ C } & \multicolumn{2}{|c|}{ A } & \multicolumn{2}{|c|}{$\mathrm{E}$} & \multicolumn{2}{|c|}{ L } \\
\hline Specification & (1) & (2) & (3) & (4) & (5) & (6) & (7) & (8) & (9) & (10) \\
\hline Intercept & $\begin{array}{c}106.88^{\star \star \star} \\
(0.000)\end{array}$ & $\begin{array}{c}96.35^{\star \star \star} \\
(0.000)\end{array}$ & $\begin{array}{c}126.01^{\star \star \star} \\
(0.000)\end{array}$ & $\begin{array}{c}100.79^{\star \star \star} \\
(0.000)\end{array}$ & $\begin{array}{c}136.53^{\star \star \star} \\
(0.000)\end{array}$ & $\begin{array}{c}139.69^{\star \star \star} \\
(0.000)\end{array}$ & \begin{tabular}{|l|}
35.762 \\
$(0.216)$
\end{tabular} & $\begin{array}{l}31.774 \\
(0.344)\end{array}$ & $\begin{array}{c}94.375^{\star \star \star} \\
(0.000)\end{array}$ & $\begin{array}{c}95.744^{\star \star \star} \\
(0.000)\end{array}$ \\
\hline Ln(CREDIT) & $\begin{array}{c}-1.696^{* \star *} \\
(0.002)\end{array}$ & $\begin{array}{c}-1.795^{\star \star \star} \\
(0.002)\end{array}$ & $\begin{array}{c}-2.329^{\star *} \\
(0.018)\end{array}$ & $\begin{array}{c}-1.919^{\star \star} \\
(0.015)\end{array}$ & $\begin{array}{c}-3.195^{\star \star \star} \\
(0.000)\end{array}$ & $\begin{array}{c}-2.896^{\star \star \star} \\
(0.001)\end{array}$ & $\begin{array}{c}0.281 \\
(0.806)\end{array}$ & $\begin{array}{l}-1.203 \\
(0.322)\end{array}$ & $\begin{array}{l}-0.358 \\
(0.736)\end{array}$ & $\begin{array}{l}-0.031 \\
(0.972)\end{array}$ \\
\hline No of service & & $\begin{array}{c}-2.103 \\
(0.593)\end{array}$ & & $\begin{array}{c}-3.116 \\
(0.386)\end{array}$ & & $\begin{array}{c}-0.163 \\
(0.976)\end{array}$ & & $\begin{array}{c}1.346 \\
(0.819)\end{array}$ & & $\begin{array}{c}-7.851 \\
(0.168)\end{array}$ \\
\hline Age & & $\begin{array}{c}2.571^{\star * \star} \\
(0.003)\end{array}$ & & $\begin{array}{c}3.496^{\star \star \star} \\
(0.006)\end{array}$ & & $\begin{array}{c}-1.283 \\
(0.268)\end{array}$ & & $\begin{array}{l}4.578^{*} \\
(0.053)\end{array}$ & & $\begin{array}{c}1.498 \\
(0.421) \\
\end{array}$ \\
\hline LISTED & & $\begin{array}{c}2.054 \\
(0.752)\end{array}$ & & $\begin{array}{l}-7.859 \\
(0.463)\end{array}$ & & $\begin{array}{l}-4.005 \\
(0.654)\end{array}$ & & $\begin{array}{l}19.084^{*} \\
(0.077)\end{array}$ & & $\begin{array}{c}8.292 \\
(0.498)\end{array}$ \\
\hline No. of observations & 82 & 82 & 82 & 82 & 82 & 82 & 82 & 82 & 82 & 82 \\
\hline Adjusted $\mathrm{R}^{2}$ & 0.0651 & 0.1432 & 0.0771 & 0.2034 & 0.2020 & 0.1982 & 0.0053 & 0.1257 & 0.0004 & 0.0505 \\
\hline
\end{tabular}

This table shows the results of univariate and multivariate regression for PSEUDO GROUP of CAEL rating score and its components' scores on the size of shadow banking activities measured by the natural logarithm of the value of all shadow banking credit services: Ln(CREDIT). No. of services is the number of services provided by a securities firm; Age is the number of years the company in operation since its establishment; LISTED is a dummy equal to 1 if the securities company is listed on the stock exchange and 0 otherwise. In the parentheses are the p-values. ${ }^{* \star}$, ${ }^{* *}$ and ${ }^{*}$ indicate significance level of $1 \%, 5 \%$ and $10 \%$, respectively.

\subsection{More insights on the LEGAL and PSEUDO groups}

In this section, we conduct further tests on the difference in LEGAL and PSEUDO groups, which hopefully, may provide some insights on the effect of shadow banking activities on the financial conditions of Vietnam securities companies. The first test is based on a report of violations by securities firms of Vietnam which received sanctions from SSC. Many of these violations are related to shadow banking activities such as: firms that conduct the credit services without permission from regulatory bodies or utilize the assets of customers to provide credit services without informing the customers, etc. We test whether the shadow banking activities of securities companies increase the probability of being in the "black-list" for violation of law and regulations. Our probit models are as follows:

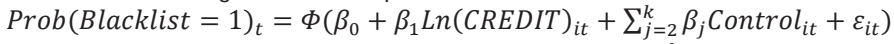

$\operatorname{Prob}\left(\text { Blacklist }_{1} 1\right)_{t}=\Phi\left(\beta_{0}+\beta_{1} \operatorname{Ln}(\text { CREDIT })_{i t-1}+\sum_{j=2}^{k} \beta_{j} \operatorname{Control}_{i t-1}+\varepsilon_{i t}\right)$

Blacklist is the dummy variable that equal to 1 if the company is in the list of sanctions by the SSC. Control variables are still the number of services, company age and dummy LISTED. We also include in the models 2 more control variables which are the natural logarithm of bad debts from shadow banking activities and provision for bad debts made by the companies. However, the results from these extra control variables (unreported) are not significant.

The second test also requires probit model. By the end of 2013, SSC published the list of securities firms that could not meet the financial safety requirements. These companies would be put under more closely supervisory by SSC. We prepare a test to see if the shadow banking activities from the securities companies have any effect on the chance that the firms get into the "safety black list" by the SSC. The model is similar to the previous one.

$\operatorname{Prob}(\text { SafetyBlacklist }=1)_{t}=\Phi\left(\beta_{0}+\beta_{1} \operatorname{Ln}(\text { CREDIT })_{i t}+\sum_{j=2}^{k} \beta_{j} \operatorname{Control}_{i t}+\varepsilon_{i t}\right)$

The results for these tests are demonstrated in Table 8.

Table 8. Further tests on effect of shadow banking activities

\begin{tabular}{|l|c|c|c|}
\hline Probability of being in blacklist in year $\mathbf{t}$ \\
\hline Sample & Full Sample & \multicolumn{2}{|c|}{ Sub-Samples } \\
\cline { 2 - 4 } & & LEGAL & PSEUDO \\
\cline { 2 - 4 } & $(1)$ & $(2)$ & $(3)$ \\
\hline Intercept & $-2.369^{* *}$ & -1.170 & $-3.971^{\star *}$ \\
& $(0.020)$ & $(0.473)$ & $(0.037)$ \\
\hline
\end{tabular}




\begin{tabular}{|c|c|c|c|}
\hline Ln(CREDIT) & $\begin{array}{c}0.072 \\
(0.145)\end{array}$ & $\begin{array}{c}-0.016 \\
(0.828)\end{array}$ & $\begin{array}{l}0.162^{* *} \\
(0.045)\end{array}$ \\
\hline No. of services & $\begin{array}{c}-0.247 \\
(0.130)\end{array}$ & $\begin{array}{c}0.014 \\
(0.953)\end{array}$ & $\begin{array}{l}-0.371 \\
(0.162)\end{array}$ \\
\hline Age & $\begin{array}{c}0.046 \\
(0.246)\end{array}$ & $\begin{array}{c}0.059 \\
(0.196)\end{array}$ & $\begin{array}{c}0.024 \\
(0.761)\end{array}$ \\
\hline LISTED & $\begin{array}{c}0.137 \\
(0.590)\end{array}$ & $\begin{array}{c}-0.194 \\
(0.518)\end{array}$ & $\begin{array}{c}0.95^{\star} \\
(0.083)\end{array}$ \\
\hline No of observation & 216 & 133 & 83 \\
\hline Pseudo-R2 & 0.0235 & 0.0147 & 0.1247 \\
\hline \multicolumn{4}{|c|}{ Probability of being in blacklist in year $t+1$} \\
\hline \multirow[t]{3}{*}{ Sample } & Full Sample & \multicolumn{2}{|c|}{ Sub-Samples } \\
\hline & & LEGAL & PSEUDO \\
\hline & (1) & (2) & (3) \\
\hline Intercept & $\begin{array}{c}-1.977^{*} \\
(0.093)\end{array}$ & $\begin{array}{c}-1.891 \\
(0.199)\end{array}$ & $\begin{array}{l}-3.190 \\
(0.151)\end{array}$ \\
\hline \begin{tabular}{|l}
$\operatorname{Ln}($ CREDIT) \\
\end{tabular} & $\begin{array}{c}0.080 \\
(0.143)\end{array}$ & $\begin{array}{c}0.032 \\
(0.606)\end{array}$ & $\begin{array}{c}0.139 \\
(0.157)\end{array}$ \\
\hline No. of services & $\begin{array}{l}-0.262^{*} \\
(0.083)\end{array}$ & $\begin{array}{c}0.118 \\
(0.561)\end{array}$ & $\begin{array}{l}-0.451^{*} \\
(0.063)\end{array}$ \\
\hline Age & $\begin{array}{c}-0.015 \\
(0.727)\end{array}$ & $\begin{array}{l}-0.050 \\
(0.367)\end{array}$ & $\begin{array}{c}0.043 \\
(0.578)\end{array}$ \\
\hline LISTED & $\begin{array}{c}0.278 \\
(0.262)\end{array}$ & $\begin{array}{c}0.153 \\
(0.607)\end{array}$ & $\begin{array}{c}0.676 \\
(0.213)\end{array}$ \\
\hline No of observation & 216 & 133 & 83 \\
\hline Pseudo-R² & 0.0219 & 0.0111 & 0.0920 \\
\hline \multicolumn{4}{|c|}{ Probability of being in safety blacklist } \\
\hline \multirow[t]{3}{*}{ Sample } & Full Sample & \multicolumn{2}{|c|}{ Sub-Samples } \\
\hline & & LEGALa $^{a}$ & PSEUDO \\
\hline & (1) & (2) & (3) \\
\hline Intercept & $\begin{array}{c}-0.799 \\
(0.382) \\
\end{array}$ & & $\begin{array}{l}-2.732^{*} \\
(0.067)\end{array}$ \\
\hline Ln(CREDIT) & $\begin{array}{c}0.041 \\
(0.349)\end{array}$ & & $\begin{array}{l}0.113^{*} \\
(0.054)\end{array}$ \\
\hline No. of services & $\begin{array}{c}-0.483^{\star \star} \\
(0.014)\end{array}$ & & $\begin{array}{l}-0.241 \\
(0.287)\end{array}$ \\
\hline Age & $\begin{array}{c}-0.016 \\
(0.767)\end{array}$ & & $\begin{array}{l}-0.018 \\
(0.835)\end{array}$ \\
\hline LISTED & $\begin{array}{c}0.061 \\
(0.855)\end{array}$ & & $\begin{array}{c}0.187 \\
(0.730)\end{array}$ \\
\hline No of observation & 216 & & 83 \\
\hline Pseudo-R ${ }^{2}$ & 0.0730 & & 0.0328 \\
\hline
\end{tabular}

aNone of the securities companies in the LEGAL group is in safety black-list

This table shows the results of probit model on the probability of a securities firm to be in the sanction black-list as well as safety black-list. Ln(CREDIT) is the natural logarithm of all shadow banking activities of a securities firm, number of services is the number of services which the securities firm provides, age is the number of year the company is in operation, LISTED is the dummy, equal to 1 if the company is listed and 0 otherwise. P-values are reported in parentheses. ${ }^{* * *},{ }^{* *}$ and * indicate the significance level of $1 \%, 5 \%$ and $10 \%$, respectively.

The probit models show very interesting results. For the whole sample, the shadow banking activities seem to have no effect on the probability of being in black-list of any kinds. The securities firms that provide more services are less likely to be in the black-lists. There is no significant result for securities companies in the LEGAL group. However, when considering the PSEUDO group, we have a different picture. The coefficients for Ln(CREDIT) are positive and significant in both sanction black-list and financial safety violation black-list. This result confirms that, to those companies that rely mostly on pseudo shadow banking activity, the more they engage in that business, the more likely they violate the regulations or their financial condition become worse. 


\subsection{Robustness check}

In the previous regressions of this paper, we used the robust standard errors to calculate the statistics used for all testing. Heteroskedasticity-robust standard errors for linear regression and probit models, cluster robust standard errors for random effect panel regression to be specific. Although we do not report here, we did use bootstrap procedure (random resampling based on my sample data, replicate 1,000 times) to obtain bootstrap robust standard errors which are used for testing. The results are similar to those reported in this paper.

\section{Conclusion}

In the project, we study the effect of shadow banking activities of Vietnam securities companies on their financial conditions to see whether these types of credit services bring more benefits or harms to the securities firms providing them. Toward this end, we look at the impact from various aspects of financial conditions of the securities firms: capital adequacy, asset quality, earnings and liquidity as well as the total impact to the whole financial condition. Using a modified version of the CAMEL rating system (CAEL) is appropriate to achieve this kind of study since it can be used as a total rating as well as component rating scheme.

We found that the size of shadow banking activities of the securities firms is negatively related to their overall financial conditions. For each component, credit services have negative impact on asset quality, capital adequacy and liquidity. The effect of shadow banking activities on the profitability of securities companies is positive, but this effect is subsumed when other control variables such as age and number of services are included.

We further divided the original sample into 2 sub-samples: the group with companies that are allowed by SSC to provide official credit activities (LEGAL group) and group with securities firms that do not meet the requirements to provide official credit and have to rely on "pseudo" services (PSEUDO group). The results indicate a stronger effect of shadow banking activities to the PSEUDO group. Further probit models also show that for firms in the PSEUDO group, shadow banking activities increase the probability of them being in the black-list of regulation violation or in the black-list of companies that could not maintain a safe and sound financial condition by SSC. There would be 2 main reasons for that. Firstly, the financial conditions of securities companies in the PSEUDO group are, on average, lower than firms in LEGAL group (measured by CAEL and its components). Secondly, the "pseudo" financial services are largely unregulated and, at the moment, out of the supervisory by regulatory bodies such as SSC. Therefore, the securities companies would have an opportunity to exploit that type of shadow banking services, bringing risks to the customers and themselves. Only when the SSC conducts an investigation or when there were conflicts between the securities firms and the customers could those problems be discovered. However, only sanction does not seem to solve the problem. From this paper, one recommendation for the State Securities Commission of Vietnam is to closely supervise the activities of the securities firms, deploy early warning tools such as CAMEL rating system and early intervene has any problems appeared that may cause risks to the companies in particular and the financial system in general.

\section{References}

Axelle Arquié and Patrick Artus. (2013). Measuring the shadow banking system in the Euro Area: What does the ECB know?, Revue d'Économie Financière, No. 109

Ben S. Bernanke. (2012). Some reflections on the crisis and the policy response, Conference on "Rethinking Finance: Perspectives on the crisis", Russell Sage Foundation and the Century Foundation, New York.

Bo Liu, Shuai Shao and Yan-Yang Gao. (2016). An Empirical Study about the influence of China's Shadow Banking on the stability of the financial system, International Journal of Economics and Finance; vol. 8, No. 4.

Francesco Ferrante. (2015). A model of endogenous loan quality and the collapse of the Shadow Banking System, Finance and Economics Discussion Series 2015-021. Washington: Board of Governors of the Federal Reserve System. [online], Available: http://dx.doi.org/10.17016/FEDS.20150.21

Ivanisevic Andrea, Ivanisevic Nebojsa, Losonc Alpar. (2012). Non-depository financial institutions and Shadow Banking System, Advanced Research in Scientific Areas conference, December 2012.

Jingyu Tang and Yanling Wang. (2016). Effect of Shadow Banking on Return - empirical study based on Chinese Commercial Banks, International Journal of Financial Research Vol. 7, No. 1, pp. 207-218.

John V Duca. (2014). What drives the shadow banking system in the short and long run?, Federal Reserve Bank of Dallas Research Department working paper 1401.

Julan Du, Chang Li and Yongqin Wang. (2016). Shadow Banking Activities in Non-financial firms: evidence from China, Fifth Symposium on Emerging Financial Markets: China and Beyond, The Chinese University of Hong Kong.

Nguyen Thanh Phuong et al. (2012). Point of view and Orientation in securities trading credit to maintain safety and soundness of 
commercial banks, Vietnam Banking Industry-level Research Project.

Nguyen Thanh Phuong, Le Quoc Tuan, Tran Anh Tuan, Nguyen Quynh Chi, Duong Ngan Ha. (2014). Financial Safety and Soundness of Securities Companies in Vietnam, Banking Academy Research Project.

Nguyen Van Ha, Tran Thi Xuan Anh, Le Quoc Tuan, Nguyen Quynh Chi. (2015). Shadow Banking, its effects to Banking Industry Safety and Soundness and Solutions, Vietnam Banking Industry-level Research Project.

R Gandhi. (2014). Danger posed by shadow banking system to the global financial system - The Indian case, International Conference "Governance \& Development: views from G20 countries", Mumbai 21 August 2014.

Stephan Luck and Paul Schempp. (2014). Banks, Shadow Banking and fragility, European Central Bank working paper No. 1726, August 2014.

Tobias Adrian and Adam B. Ashcraft. (2012). Shadow Banking: a review of literature, Federal Reserve Bank of New York Staff Reports, No. 580, October, 2012.

Tobias Adrian, Adam B. Ashcraft, Nicola Cetorelli. (2013). Shadow Banking Monitoring, Federal Reserve Bank of New York Staff Report No. 638, September 2013.

Tobias Adrian. (2014). Financial stability policies for shadow banking, Federal Reserve Bank of New York Staff Report No. 664, February 2014.

Xiao-Peng Zou, Yu Xiao Pang and Hui-Lin Zhu. (2012). The study between shadow banking and financial fragility in China: an empirical analysis based on the co-integration test and error correction model, Springer Science+Business Media B.V.2012

Yoshiharu Maeno, Kenji Nishiguchi, Satoshi Morinaga \& Hirokazu Matsushima. (2014). Impact of Shadow Banks on financial Contagion, arXiv:1410.4847 [q-fin.RM] (cited as required, available to download from https://arxiv.org/ttp/arxiv/papers/1410/1410.4847.pdf)

Zoltan Pozsar, Tobias Adrian, Adam Ashcraft and Hayley Boesky. (2010). Shadow Banking, Federal Reserve Bank of New York Staff Reports, No. 458, July 2010.

Financial Stability Board, Global Shadow Banking Monitoring Report, 2012

Financial Stability Board, Global Shadow Banking Monitoring Report, 2013

Financial Stability Board, Global Shadow Banking Monitoring Report, 2014

Financial Stability Board, Global Shadow Banking Monitoring Report, 2015 